\title{
Indicators for Spatial Planning and Territorial Cohesion: Stakeholder-Driven Selection Approach for Improving Usability at Regional and Local Levels
}

\author{
Ainhoa González (a), Gavin Daly (a), Philip Pinch (b), Neil Adams (b), Visvaldis Valtenbergs \\ (c), Malcolm C. Burns (d) \& Hjalti Johannesson (e) \\ (a) National Institute for Regional and Spatial Analysis (NIRSA), National University of \\ Ireland Maynooth, Maynooth, Ireland. \\ (b) Urban, Environment and Leisure Studies, London South Bank University, Urban, London, \\ UK. \\ (c) Vidzeme University of Applied Sciences, Valmiera, Latvia. \\ (d) Universitat Politècnica de Catalunya, European Projects Office, Barcelona, Spain. \\ (e) University of Akureyri, Research and Development Centre, Akureyri, Iceland.
}

\begin{abstract}
Reformed EU Cohesion Policy aims at delivering a coherent investment policy to achieve the goals of the Europe 2020 Strategy and to reduce regional disparities. Spatial indicators present a means for measuring progress towards agreed policy goals, and for supporting integrated place-based approaches to policy implementation. Despite the wide range of spatial indicators available, development of a standardised approach in support of Cohesion Policy has received little empirical attention. A set of key indicators has been identified in a stakeholder-driven process using five case study territories. The methodological approach applied is presented and the resulting indicators critically appraised with regards to their applicability and potential for assisting improved integration between Cohesion Policy and spatial planning.
\end{abstract}

Keywords: Spatial Planning, Territorial Cohesion, Indicators, Stakeholder Participation, Europe. 


\section{Introduction}

European Union (EU) Cohesion Policy, which represents one-third of the EU budget, is undergoing a process of far-reaching reform. 'Intervention logic', 'performance indicators', 'monitoring' and 'evaluation' are all the buzzwords of a new regime which is clearly focused on delivering a coherent investment policy, achieving the EU-wide policy goals and reducing economic and social disparities in an era of scarcer resources. Against the background of the economic crisis and fiscal retrenchment, and concentrated around eleven thematic priority objectives, Cohesion Policy has now been brought into line with the headline targets of the Europe 2020 Strategy (CEC, 2010) and integrated into macro-economic governance through the new European semester budgetary process. National policies in respect of a whole range of policy agendas, such as employment, research and development, Greenhouse Gas (GHG) emissions, energy and social inclusion are now subject to annual peer review through forensic monitoring and the issuing by the European Commission of Country-Specific Recommendations for each Member State, which are required to be systematically taken into account through policy reform programmes at the national level (DALY and GONZÁLEZ, 2013).

At the same time, the severity of the economic crisis has interrupted the long-run trend towards territorial convergence, with geographical disparities and uneven regional development increasing markedly throughout the EU (CEC, 2014). Reduced national budgets for public investment and policies to deleverage debt burdens together with Europe 2020 targets are now key drivers of spatial development trends and new core-periphery geographies. The addition of 'territorial cohesion' to the twin goals of economic and social cohesion, as a fundamental objective of the EU in the Lisbon Treaty, has more recently revived interest in 'integrated place-based' approaches to Cohesion Policy (BARCA, 2009; 
MENDEZ, 2012). This move has increased the importance of strategic spatial planning policy - which had been largely overlooked since the publication of the European Spatial Development Perspective (CEC, 1999). Spatial planning seeks to influence the integrated management of spatial change and the future distribution of activities through "framing decisions, actions, projects, results, and implementation, incorporating monitoring, evaluation, feedback, adjustment and revision" (ALBRECHTS, 2013, p171). The inherent potential for spatial planning to promote territorial cohesion through a more balanced social and economic development of regions, and improved competitiveness, has more recently been recognised in a number of high-level EU policy documents which encourage Member States to 'cross-fertilise' the principles of territorial cohesion into their national spatial planning mechanisms (CEC, 2011a; CEC, 2011b).

A key criticism of the Europe 2020 Strategy and its 'one-size-fits-all' headline national targets is that it is 'spatially blind', but not spatially neutral, and carries with it the potential to exacerbate regional inequality and uneven development, contrary to Cohesion Policy goals (CEC, 2011b). For example, the recently published Sixth Cohesion Report notes that "because manufacturing is spatially concentrated, it is unrealistic to expect that all regions can reach the national target for R\&D spending" (CEC, 2014, p29). This example, which also applies to other policy areas, is an explicit recognition that different types of territories and regions are endowed with diverse combinations of resources and specificities, putting them into very different positions to contribute to the achievement of the goals set by Europe 2020. Despite this, the rescaling of national Europe 2020 to the sub-national level (e.g. regional and local levels) and the connection to spatial planning policy has received little empirical attention in academic literature. 
It is in this context that the ESPON ${ }^{1}$ funded research project 'Key Indicators for Territorial Cohesion and Spatial Planning (KITCASP)' sought to address this gap in empirical research and to identify a common core set of spatial planning indicators that could be applied across the Member States as a monitoring framework in support of reformed Cohesion Policy. The purpose of this paper is to present the methodological approach developed and applied by the KITCASP project for the identification and selection of indicators and to critically appraise their applicability. Using five case study territories, the paper presents the results of the common policy themes identified and the associated indicators selected through an in-depth stakeholder-led process. It further discusses the difficulties encountered when developing a set of common indicators across differing territorial circumstances, and critically examines the final selected indicators in view of their benefits and limitations. Within the foregoing context, this paper makes a critical first step, albeit preliminary, in investigating how the relationship between spatial planning and Cohesion Policy can be better integrated as an important monitoring tool for the implementation of place-based approaches to the Europe 2020 Strategy, at and beyond the national level.

\section{Methodological Approach: Building on Shared Understanding}

KITCASP was a transnational stakeholder-driven research project (under Priority 2, Targeted Analysis, of the ESPON 2013 Programme). It was borne out of an objective shared by the public authorities responsible for spatial planning in the five stakeholder territories, comprising the Basque Country, Iceland, Ireland, Latvia and Scotland to investigate the potential for the development of a coherent set of common indicators to monitor the implementation of national spatial planning strategies and territorial development policies,

\footnotetext{
${ }^{1}$ The mission of the ESPON 2013 Programme is to support policy formulation in relation to territorial development and cohesion through the provision of a robust evidence base and the identification of territorial development trends, challenges and opportunities. See www.espon.eu
} 
in the context of EU Cohesion Policy. While Ireland and Latvia are Member States, Iceland is an ESPON participating country, and both Scotland and the Basque Country are 'national' territories with exclusive competency in spatial planning. Each of the five territories had well-advanced, if not fully approved national spatial planning strategies. Furthermore, the principle of territorial cohesion was already well integrated into national policies within each of the five case study territories. While key territorial development challenges vary considerably across the territories and thus determine the territorial policy orientations and objectives, existing similarities enabled the identification of common policy priorities as discussed below.

The stakeholder-driven approach entailed proactive engagement with policy-makers and planning practitioners to develop a set of indicators which reflect national spatial policy priorities. Participatory approaches to indicator selection present learning opportunities and shared understanding of the problem at hand (DONNELLY et al., 2006; GONZÁLEZ et al., 2011, LEGACY, 2010). The KITCASP stakeholder dialogue exchanges provided significant insights into various approaches to the identification, development and formulation of spatial planning policies across the case study territories. This included an examination of the availability and use of supporting evidence (in the form of baseline data or regularly monitored indicators) both at national and EU level - including through ESPON .

An important aim of the KITCASP project was to ensure high usability and concrete implementation of the final selected indicators by policy-makers in each of the stakeholder territories. However, in order to be useful and effective, indicator sets need to be contextspecific, formulated to address policy priorities and development objectives in each territory, and measure direction of change in achieving these priorities over time (DALY and 
GONZÁLEZ, 2013; NICHOLSON and FRYER, 2002; SCHOMAKER, 1997). They need to provide adequate level of assessment detail to support evidence, ensure measurability within set time-frames and existing resources, and effectively inform decision-making (GONZÁLEZ et al., 2011; NICHOLSON and FRYER, 2002). The critical position of indicators and their associated monitoring frameworks at the interface between scientific research, policy and politics is emphasised by ESPON, as well as by international literature (GONZÁLEZ et al., 2011; ESPON, 2007; SMEETS and WETERINGS, 1999). However, it is also acknowledged that changes occur in various policy and planning areas even without specific policy interventions. Indicator values are termed to have a 'deadweight' when outcomes cannot be attributed to a policy (AMBROZIAK, 2014; NAGY and LÓRÁND, 2013; POTLUKA, 2010). Although 'deadweight' factors may want to be examined to identify and understand other drivers of change, whether the trend is a direct result of a policy (e.g. tax incentives) or it follows an already established pattern is not critical in the context of spatial planning if the policy is still being achieved.

In consultation with the stakeholders, it was agreed that a maximum of 20 core indicators were to be identified as this was considered to represent a manageable and implementable set. This core set would be supplemented with a tailored set of discretionary (or casespecific) indicators for individual territories. The advantage of referring to indicators from a common core set derives from the consistent measurements, as well as from crossterritorial comparability and benchmarking. On the other hand, case-specific indicators have the potential to more precisely address particular issues in the various case study territories. This approach provided flexibility for stakeholders to adapt the final set to their specific 
policy objectives or territorial characteristics while supporting comparative benchmarking of territorial performance.

Figure 1 about here

The first phase of the project focused on identifying common priority spatial policy goals for all the five stakeholder territories through a bottom-up approach (Figure 1). This was achieved by undertaking a structured and systematic desktop review of national policy statements that define development policies, as well as the spatial planning goals and priorities for each of the five territories (e.g. Icelandic National Planning Strategy 2013-2024

- ICELAND PLANNING AGENCY, 2012; Modification to the 1997 Spatial Planning Guidelines BASQUE GOVERNMENT, 2012; National Development Plan 2007-2013 - GOVERNMENT OF LATVIA, 2007; National Planning Framework for Scotland 2 - THE SCOTTISH GOVERNMENT, 2009; National Spatial Strategy 2002-2020 - GOVERNMENT OF IRELAND, 2002). The analysis was supplemented with structured stakeholder workshops and focus groups at national level, as well as a number of expert interviews (Table 1). Given that KITCASP was a stakeholder-driven ESPON project, stakeholders for each case study territory were defined from the onset. Additional stakeholders and experts were selected on the basis of their expertise and role in spatial planning and policy-making. In Ireland, for example, stakeholder engagement was closely paired with the work of the Regional Planning Indicator Development Working Group which led to consultation with the Regional Planners Network (RPN), amongst others.

Table 1. Stakeholder organisations consulted and involved in KITCASP. 


\section{Policy Priorities as Themes for Indicator Selection}

The policy review and stakeholder consultation produced a set of four agreed thematic policy areas which formed the basis for indicator identification, categorisation and selection (see Table 2).

[INSERT TABLE 2 about here

Stakeholder workshops revealed a considerable degree of consensus about interpretations of key concepts such as economic competitiveness and resilience along with the need to focus on the spatial dimension of these concepts (i.e. the 'where of things'). The concept of 'resilience' is an increasingly important policy discourse in regional studies literature (e.g. CHRISTOPHERSON et al., 2010; COAFFEE, 2013; HUDSON, 2010; MARTIN, 2012; BRISTOW and HEALY, 2014). Stakeholders in Scotland reflected this and argued that resilience was a more relevant term than competitiveness as the latter was subject to change over time, leaving territories more vulnerable to the negative impacts of globalisation. Concerns were also raised about increasing conflicts and tensions between economic and environmental goals. Overall, this theme resonates with European and national policy agendas where promotion of competitiveness and job creation are critical and challenging within the economic crisis and global competition contexts.

The workshops revealed diverse understandings of territorial cohesion and the contradictory forces at stake both within and between stakeholder territories. All stakeholders agreed in principle that territorial cohesion related to the pursuit of more balanced patterns of development and reducing disparities. However, in the Basque Country this related this to achieving a balance between the three main cities, smaller centres and rural areas, whilst in 
Scotland the importance of context-sensitive local solutions to respond to the diverse challenges facing territories was emphasised. More generally concerns were raised about the extent to which the promotion of more balanced patterns of development (a policy priority in the spatial planning agenda of many Member States) is reflected in the reality of the economies of many countries being increasingly driven by a small number of large urban centres, primarily the capital regions such as Riga in Latvia, Reykjavik in Iceland and Dublin in Ireland. These differences resulted in usage of the integrated spatial development theme which encompasses a diverse range of ideas, concepts and policy ambitions; these diverse approaches can make measurement and evaluation problematic.

Both the economic competitiveness and integrated spatial development themes have an impact on social inclusion, cohesion and quality of life. Stakeholders' perceptions on the subjective and objective measures of quality of life, absolute and relative measures of equality or the nature of 'cohesion' shaped relevant indicator considerations. This theme serves the overall Europe 2020 objective for the well-being of populations, which is a core objective of spatial planning policy, and for reducing social disparities and inequalities across the EU.

Stakeholders at all workshops identified issues relating to environmental sustainability and natural resource management as important, particularly in the context of the spatial characteristics and environmental qualities of the case study territories. Moreover, the need to reduce GHG emissions, improve natural resource management, protect landscapes, habitats and biodiversity, and promote environmental sustainability are influential policy drivers internationally. The Scottish Government, for example, has committed itself to ambitious climate change targets, and mitigation and adaptation to climate change are 
powerful drivers for national spatial policy. Similarly, landscape protection policies are high in the Scottish and Basque Government agendas, and biodiversity protection and water resource management are requirements under EU legislation (e.g. Habitats Directive 92/43/EEC and Water Framework Directive 2000/60/EC).

\section{Indicators for Spatial Planning and Territorial Cohesion}

Once the common themes were agreed with the stakeholders, the objective was to identify a set of core and discretionary indicators that (a) most suitably addressed the agreed themes and addressed relevant EU policy objectives (e.g. TA2020, Europe 2020 and national policy statements and spatial strategies); (b) were able to be mapped and thus examine spatial trends, patterns and linkages (all necessary to inform spatial planning); (c) were sensitive to change, thus providing a timely contribution to decision-making; and (d) were easy to understand by policy-makers (i.e. communicating scientific results in a concise and accessible manner). This filtering and refinement process also served as a systematic check regarding data availability and spatial resolution/scale and involved a review of the potential of existing ESPON and national spatial datasets to populate indicators and provide practical monitoring frameworks. The selection of core economic and social indicators was challenging as a high degree of territorial autonomy on these matters remains, although this is rapidly changing through the application of the Europe 2020 Strategy and its harmonised headline targets. In contrast, the selection of integrated spatial development and environmental indicators was more clear-cut as there is largely a common European agenda in terms of territorial concepts and environmental policy which is applicable to all the territories (see Table 3). 
Discretionary indicators address explicit territorial issues of a given case study (rather than being of importance across the case study territories). For example, in the Irish case study the project team worked closely with the RPN in the development of indicators to measure progress in implementing the Regional Planning Guidelines 2010-2022. The KITCASP project had a significant influence on the design of the final indicators set for the RPN project and illustrates the value of the KITCASP project to address case-specific territorial contexts.

The policy objectives (Table 3) derive from existing European and/or national policy and are used to monitor indicator performance and, in this way, progress towards the achievement of such objectives. They enable analysis and interpretation of indicator values, and need to be supported by regular monitoring to effectively identify changes and trends over time. Nevertheless, it was beyond the scope of the KITCASP project to establish whether such indicator values should go up or down. More importantly, indicator values must be interpreted in a context-specific manner, taking into account territorial structures and priorities (e.g. population density may give an indication of the characteristics and potential of an area, but population density targets will differ for rural and urban areas).

\section{Economic Competitiveness and Resilience}

The most commonly used indicator for measuring the economic strength of a territory is 'Gross Domestic Product (GDP) per capita'. There are numerous criticisms of GDP as a measure of economic performance and activity, particularly in respect of the fact that it does not take sufficient account of environmental and social externalities (NEF, 2005; WWF, 2008). However, GDP is the most widely measured and understood economic activity metric and, therefore, consistently selected by the stakeholder territories. The project team 
decided that GDP per capita should be complemented with 'Gross Value Added (GVA) per capita' to provide options for policy-makers in relation to measuring productivity. While GDP/GVA are the most commonly accepted economic metrics, they are not necessarily linked with employment growth. A key objective of Europe 2020 and all national governments is to provide for job-rich economic growth. In the light of this, 'employment rate of population aged 20-64' was also included as a key economic metric, as suggested and supported by the majority of stakeholders.

Innovation is a cornerstone of current EU strategies for economic recovery and it is equally high on national governments' agendas. Knowledge and innovation are seen as key drivers of economic development. Research and Development (R\&D) is also a key theme of the Common Strategic Framework for Cohesion Policy post-2013 (EC, 2012). R\&D is also considered a key component of eco-efficiency, development of a low-carbon economy and the need for energy efficiency. For this reason, 'total R\&D expenditure as \% of GDP' was selected as a metric to assess local efforts in the development of innovation strategies.

Increasing exports is a central element of all the stakeholder territories' strategies for achieving competitiveness, foreign income and, as a consequence, territorial development. There was a level of consensus around this objective but no clear indicator emerged. Ireland proposed 'Foreign Direct Investment (FDI)', the Basque Country 'balance of external trade', Latvia 'FDI contributions', and Scotland referred to both FDI and value of exports. After consultation with all stakeholders, it was agreed that 'balance of external trade' was a suitable compromise indicator to capture this component of economic competitiveness. Finally, a clear message from the Scottish stakeholders was the need to include 'resilience' as key concept to buffer vulnerable territories from the asymmetries and capricious nature of 
globalisation. As no clear indicator emerged from the stakeholder territories, and due to scale and consistency limitations, the proxy indicator of 'economic structure' was put forward in order to provide policy-makers with some insights into economic diversification and resilience as part of territorial development. Imbalances in the sectoral share of employment would be indicative of territorial difficulties for economic adaptation.

\section{Integrated Spatial Development}

Integrated spatial development implies promoting a coherent physical organisation of space according to an overall strategy. There was a high level of consensus across the case study territories on 'population density/population change' as a basic measure of territorial development. Monitoring demographic change is essential to capture regional activity decline/growth and for planning housing/service provision. Increased population density in urban areas, for example, responds to the policy objectives of compact urban form, polycentricity, smart cities and sustainable development. Settlement and housing are key outputs from spatial planning processes. Therefore, measuring 'house completions', particularly the alignment of new housing development with infrastructure and services, was considered essential. Sustainable transport is a key objective of EU climate change and Cohesion Policy (EC, 2010, 2012). Integrated land-use and transport planning is also a key competency of spatial planning. It was therefore decided, in consultation with the stakeholders, to put forward 'modal split' as a core indicator. Although there was a slight variation when referring to transport indicators across the case studies, there was consensus for selecting this indicator as it has the ability to capture trends on car dependency (and subsequently act as a proxy for fossil fuel consumption and climate change related issues). 
Spatial planning is, to a large degree, about managing competing demands for land. As territories become more urbanised retaining land for other uses (agriculture, recreation, forestry, habitat protection, etc.) and preventing fragmentation is at times challenging. A clear demand for a metric which measured 'land-use change' was articulated by the stakeholders, and the project team concurred that there are merits in adopting such indicator, particularly in light of the EU Coordination of Information on the Environment (CORINE - EEC, 1985) and the fact that land-use change reflects strongly on territorial capital. This indicator, combined with composition, pattern and density of urban growth (e.g. geographic distribution of population density and house completions) can provide significant insights into the shaping of Europe's settlement structure (SIEDENTOP and FINA, 2012). Monitoring land-use change enables examination of unwanted settlement trends, such as urban sprawl, as well as identification of loss of significant habitats. Such an indicator also captures landscape protection issues which were of concern for the Scottish and the Basque Country stakeholders in particular. Finally, 'access to services' was selected which can serve to alert policy-makers to the need to take action to create more balanced territories and avoid spatial discrimination. Due to negative demographic trends, in some territories access to services and the political issue of maintaining adequate levels of public services has gained increasing salience in the context of EU-wide fiscal consolidation (ESPON, 2013). Hospitals and schools were selected as two key high-order services and were considered to provide a bellwether for wider service provision. However, other services could equally be used where spatial data were available at an appropriate scale.

\section{Social Cohesion and Quality of Life}

Indicators selected for this theme are clearly linked to other themes in that social cohesion and quality of life are both a result of and input for economic development. Equally, 
integrated spatial development and high environmental quality also impact on social cohesion and quality of life. A key component of Europe 2020 is to foster innovative territories, social capital and educational attainment in order to improve the match between skills supply and labour force requirements in high skilled sectors requiring tertiary qualifications such as ICT, engineering, science, health and financial services. Education is central to economic activity, and different types of economic activity draw upon and require different types of knowledge and skills (HUDSON, 2011). There was a high degree of consensus for inclusion of an indicator relating to education. The project team opted to select the key Europe 2020 indicator of 'population aged 30-34 with tertiary education' to provide a metric of innovative capacity. An absence of population within this cohort with tertiary education can point to structural deficiencies within the territorial economy whereby highly-qualified skilled workers are electing to migrate to other territories with higher quality employment opportunities. This is of particular significance in larger regions and metropolitan areas, where a transition towards more knowledge-intensive sectors has strong impact on development and the economy (ERIKSSON and HANSEN, 2013).

Reducing the risk of poverty is a further key objective of Europe 2020 with a headline target of at least 20 million fewer people in or at risk of poverty and social exclusion by 2020 (CEC, 2010). The primary policy tools to reduce severe material deprivation and, consequently, poverty are measures that increase employment and, as a result, there is a clear link with indicators in the economic competitiveness and resilience theme. The project team considered that the most appropriate indicator was the Europe 2020 indicator of 'population at risk of poverty', in order to strengthen coherence with the broader EU policy context and objectives. 
International research points to access to green spaces as a key determinant of human health and well being (BURLS, 2007). Spatial planning has a fundamental role in improving accessibility to green spaces through the implementation of land-use strategies. Therefore, the project team considered that 'green space accessibility' should be included as an indicator despite the lack of unanimity across the stakeholder territories for this indicator, which reflected the differing territorial contexts.

There are several attempts globally to measure sustainable development and quality of life. The most pertinent examples include the Physical Quality of Life Index, Human Development Index, Index of Sustainable Economic Welfare, Happy Planet Index and the Better Life Index (OECD, 2013; UNDP, 2013; NEF, 2012; CLIFFORD and COBB, 1994; MORRIS, 1980). The Icelandic stakeholder proposed the 'Well-being Index' developed by the World Health Organisation (WHO, 1998). This index aims at measuring well-being from a mental health perspective and is calculated on the basis of responses to five statements that capture personal feelings with regards to happiness, calmness, activity, rest and interest in daily life. It captures better aspects of social cohesion and quality of life than the gender gap (proposed by the Basque Country and Iceland) and the Gini coefficient which measures income differentials (proposed by Latvia and Iceland). Well-being has been criticised for being something of a vague concept, but it can be measured by synthesizing several indicators which strongly correlate with it (e.g. self-reported quality of life, material living conditions and requirements for sustaining well-being over time). Despite conceptual and methodological difficulties, it was considered important to put forward indicators which attempted to measure well-being outside of narrow economic and demographic metrics especially because macro-economic statistics do not always account for what people really perceive about the state of their lives. Moreover, the importance of measuring well-being 
has been high on the agenda of United Nations Economic Commission for Europe, Organization for Economic Co-operation and Development and Eurostat who aim to develop better metrics for human well-being and sustainability (EUROSTAT, 2013; OECD, 2013; UNECE, 2012).

Finally, the age vibrancy of the population is of critical importance to sustain social cohesion and quality of life. As spatial planning is a future-oriented discipline, the evolution of the demographic profile can provide early indication of future territorial needs, particularly in respect of service provision but also for the future of the labour force and municipal budgets. An aging population can also point to demographic deficits where young people are migrating away from certain territories to benefit from better opportunities. The project team considered that a metric for 'dependency ratio' was therefore important. The indicator was proposed by Ireland and supported by the 'ageing index' proposed by the Basque Country and the 'healthy life expectancy' proposed by Scotland. Although there are no policy objectives set for this indicator, it is considered highly relevant for service planning.

\section{Environmental Resource Management}

There was high consensus on the indicators associated with this theme, which support not just spatial planning but also associated Strategic Environmental Assessments to determine the potential for significant environmental impacts of (policy) plan or programme implementation (CEC, 2001).

Promoting decentralised, secure and environmentally friendly production and use of renewable and low carbon energy are core objectives of Europe 2020 and TA2020 as a means to building a resource efficient and sustainable economy (CEC, 2010; EU, 2011). 
'Renewable energy production' was put forward by the stakeholder territories as a key metric for sustainability and energy security. Similarly, EU climate policy has developed into a major policy agenda and a key cross-cutting focus of Europe 2020, Cohesion Policy and TA2020 (CEC, 2010; EC, 2012; EU, 2011). Mitigating and adapting to anthropogenic climate change is also a major focus of all stakeholder territories, with binding targets assigned to reduce 'GHG emissions' and mandatory reporting requirements. Given the urgent importance of this issue, this was an obvious indicator for selection.

In order to reflect the issue of adaptation to climate change, the project team put forward 'population at risk of flooding' as a proxy indicator for promoting climate change adaptation, risk prevention and management - there was a high degree of consensus across the stakeholder territories for this indicator. The Floods Directive (CEC, 2007) requires all EU territories to map flood prone areas, which can readily be translated into social vulnerabilities to climate change, of which increased (coastal and fluvial) flooding arising from intense weather events is projected to be a key consequence. Spatial planning can act as a key mitigating mechanism in increasing the preparedness of national, regional and local governments to extreme climatic events.

Across the EU, the implementation of the Habitats Directive $(E C, 1992)$ has given rise to the development of the Natura 2000 network of Special Areas of Conservation and Special Protection Areas. The Natura 2000 network is the EU's flagship initiative for protecting biodiversity and promoting ecosystem services, including green infrastructure. Given the common reporting requirements under the Habitats Directive, it was considered that the 'number and status of protected European habitats and species' was an appropriate indicator for incorporating the key issue of nature protection. There was a high degree of 
consensus as biodiversity protection is a principal objective of all stakeholder territories (although the wording of the indicator put forward by each territory varied quite significantly - e.g. 'number of designated sites' in Scotland versus 'area or status of breeding birds' in Latvia).

The Water Framework Directive (WFD - CEC, 2000) will have a significant impact on spatial planning over the next two decades with strict reporting requirements in 2015, 2021 and 2027. Although 'water quality status' was an indicator solely proposed by Ireland (with Scotland referring to 'river water quality' and the Basque Country to 'water consumption'), there were clear merits in including an indicator for water quality given the common WFD reporting requirements.

\section{Discussion: Towards a Joined-Up Approach to Monitoring Spatial Planning Implementation and Territorial Cohesion}

The concept of territorial cohesion has been criticised for its lack of definitional clarity and for its range of meanings depending on individual and/or sectoral perspectives (DALY and GONZÁLEZ, 2012). However, there is also generally broad agreement that the term highlights the need for a more spatially balanced and sustainable development through geographically tailored interventions that collectively address the need for an integrated territorial perspective in policy implementation and evaluation (BARCA, 2009; DALY and GONZÁLEZ, 2012; DUHR et al., 2010; MEDEIROS, 2010). This orientation can be supported by the current general shift towards evidence-informed spatial planning policy (DAVOUDI, 2006; FALUDI and WATERHOUT, 2006). The need for a greater empirical understanding of territorial development policy decisions and evidence-informed performance monitoring has 
been hastened by the ongoing European financial crisis and the need to ensure greater optimisation, coordination and justification of policies, both sectorally and spatially (DALY and GONZÁLEZ, 2013).

One of the key challenges in implementing the now required enhanced performance monitoring, oversight measures and reporting is that over the past decade there has been a very significant increase in the range and availability of spatial datasets on an ever wider series of topics collected at EU, national and regional levels, not least as a result of ESPON research (DALY and GONZÁLEZ, 2013). European initiatives (e.g. Al, 2003; EEA, 2012), and a wide number of international, European and national studies (e.g. EUROSTAT, 2013; GONZÁLEZ et al., 2011; UNDESA, 2007; UNEP, 2012) have developed indicator sets in support of sustainable development. More recently, a number of studies have focused on developing indicators that address territorial cohesion (e.g. ESPON, 2012a), some of which focus on specific aspects, such as the impact of rural development policies on spatial cohesion (e.g. COPUS, 2010; OOSTINDIE and VAN BROEKHUIZEN, 2010). However, the use of these data to underpin evidence-informed spatial policy-making has been typically suboptimal, partly due to the sheer breadth, fragmentation and compartmentalised nature of the information available. This short-fall points to the need for the development of key indicators which have the ability to distil these data and translate complex relationships about territorial phenomena in a way that can be easily understood by policy-makers to provide usable and reliable signals of important trends over time.

The themes and associated indicators developed by the KITCASP project through a stakeholder-led approach present a first attempt in developing a standardised method in the use of spatial data to inform Cohesion Policy, as well as to coordinate monitoring 
approaches across the EU, and thus provide systematic national analytical experience to inform and take forward the Europe 2020 Strategy. At the same time, KITCASP indicators harness the considerable resource which has been developed by over a decade of panEuropean ESPON territorial research to bring together the European dimension with national, regional and local perspectives, information and analysis - including projects such as INTERCO (Indicators of Territorial Cohesion - ESPON, 2012a) and TPM (Territorial Performance Monitoring - ESPON, 2012b).

The potential of the KITCASP methodological approach lies in the innovative iterative stakeholder-driven selection of themes and indicators. It is acknowledged that the outcomes of such exchange depend entirely on the choice of stakeholders (GONZALEZ et al., 2011), as it is likely that other representatives with different agendas would have identified different priorities. This could also be the case if the process had been undertaken at a different point in time. Nevertheless, the bottom-up approach enabled direct incorporation of concerns, perspectives and knowledge of stakeholders with key roles in the spatial territory agendas.

When developing the policy priority themes, each of the case studies shared territorial agendas and interests, particularly in respect of their relative peripherality to the European core. However, they also displayed significant geographical differences in terms of territorial development, physical attributes, challenges, policy drivers and governance. While all the territories had a common commitment to strategic spatial planning, there were also some substantial disparities in terms of planning systems and cultures. These heterogeneous conditions are common throughout all Member States and were recognised at the project outset as a central challenge for the identification of a consistent and coherent indicators set - including any future rolling-out of the project findings beyond the five stakeholder 
territories. Linking the policy themes to EU policy and legislation ensured transferability of the themes and the associated indicators to other Member States. Moreover, the inclusion of discretionary indicators, albeit specific to the case-study territories, provide the flexibility to adapt the set to other particular policy contexts and development priorities.

Despite the apparent benefits of implementing the KITCASP approach and indicators, a number of limitations remain to be addressed. These limitations largely relate to data availability and scale issues that affect the applicability of indicators, and which are associated with, and can be addressed by, monitoring mechanisms. A review of existing indicators and supporting data revealed that each of the stakeholder territories exhibit differing data availability constraints, including conflicting nomenclature and definitions in the unit of measurement. In some instances, these data limitations presented particular problems in populating the final set of core indicators. For example, the 'population aged 3034 with tertiary education' indicator was worded to align it with the Europe 2020 Strategy targets, but different age bands are noted across the case study territories which will require some recalibration of data gathering to ensure consistency (e.g. 20-39 for Iceland, 16-64 for Scotland). Similarly, some indicators are collected under different units of measurement across the case study territories. This was the case for modal split, where some countries measure the percentage of population commuting by public transport, foot, bicycle and private cars (the Basque Country and Scotland), and others focus on the accessibility to public transport (e.g. 'population within 500 metres of public transport' suggested in Ireland or 'access to public transport' in Latvia). This will require a standardisation of data gathering approaches to harmonise the indicator and enable comparability. Systematic and harmonised data gathering has been promoted through the implementation of a number of EU directives facilitating timely population of indicators and their comparability. This is 
reflected in the majority of KITCASP environmental indicators, such as 'water quality status', under the WFD (CEC, 2000), 'GHG emissions' reporting under the GHG trading Directive (EC, 2003) or 'number and status of protected European habitats and species' under the Habitats Directive (EC, 1992).

The level of detail of available data, or the scale at which data are collected, also affects the usability of indicators for spatial planning at the territorial and local levels. The spatial resolution of data collection and presentation clearly matters for understanding trends. The core set of indicators relies on data collated at different scales. There is often a mismatch between the data being collected at national, regional and local levels for spatial planning and that being collected at the pan-European scale for reporting requirements. Many of the ESPON datasets are collected at national or NUTS I level (the first or most generic level of the Nomenclature of Territorial Units for Statistics geocoded standard for referencing the administrative divisions in the EU), such as balance of external trade, well-being index, GHG emissions or renewable energy production. While this is beneficial for trans-national comparative research and benchmarking (such as that undertaken to date by ESPON), it is of extremely limited functionality when undertaking national level spatial planning. For small national territories such as Iceland and Latvia, NUTS II and even NUTS III level data fail to capture substantial disparities between the metropolitan areas and hinterlands. Higher resolution datasets, collated at the local level, are better suited to inform regional and local policy- and plan-making as they portray realities at a more meaningful spatial scale. Adopting the scale of available data can potentially compromise indicator assessment detail and thereby affect the accuracy of the information supporting the formulation of policy objectives (GONZÁLEZ, 2012). Scale issues have already been tackled by some EU data collation efforts; this is the case of CORINE with a resolution increase from 25 hectares in the 
1996 and 2000 datasets to 5 hectares in the identification of land-use changes between 2000 and 2006. National efforts are also leading to an increasingly rich resource of data at lower spatial scales (i.e. higher resolution) which are more meaningful as they better reflect the territorial complexities at local levels, and which are decisive in spatial policy decisionmaking processes and the territorial cohesion agenda. Nevertheless, and as noted above, such local data gathering efforts are not making use of consistent unit of measurements, nomenclature, etc. with consequent clear implications on their applicability, transferability and comparability. In addition, data collation periodicity varies, some datasets being collected annually while others every six years (e.g. Habitats Directive). This implies that indicator assessment is constrained by availability of data updates which may affect the timely identification of changes/trends. Such temporal reference considerations must be taken into consideration when interpreting policy implementation assessment results, and when informing future policy objectives. Moreover, lack of data sharing mechanisms or centralised data systems results in stakeholders often being unaware of data of relevance to spatial planning being collected at EU, national or local levels. This can lead to duplication of data collection efforts and under-utilisation of resources. Therefore, there is strong potential for ESPON, and other EU initiatives such as the Infrastructure for Spatial Information in Europe (INSPIRE - EC, 2007), to play a key role in assisting national stakeholders to develop a joint approach that facilitates the creation of centralised inventories of available spatial data. This can be achieved through promoting greater harmonisation of spatial data collection around specific themes of relevance to spatial planning and territorial cohesion.

\section{Conclusion}

The foregoing analysis leads to three broad conclusions. Firstly, throughout the project period, working extensively with national and sub-national stakeholders directly involved in 
territorial policy-making, it is clear that there is a strong interest in developing more evidence-informed monitoring frameworks for spatial planning and strengthening the connection to Cohesion Policy. However, knowledge of the overarching headline targets of Europe 2020, which are driving national reform policies in all Member States and which are central to Cohesion Policy, remains generally very weak and often not considered directly relevant to stakeholders' daily work. This is largely due to the abstract aspatial nature of the Europe 2020 targets which do not currently take into account regional and territorial specificities.

Secondly, the KITCASP project has demonstrated that a methodology can be developed and adapted to five quite diverse territories to produce a set of common and discretionary spatial indicators, providing a compelling case for extending the approach across the EU. The development of indicators can act as an important bridge between spatial planning and Cohesion Policy, on the one hand, and allow for more fine-grain monitoring at a subnational, national and supra-national levels, on the other. Due to the highly variegated characteristics of the European territory, a nested hierarchy of common and discretionary indicators can provide for better understanding of different geographical areas across Europe and help to identify and select the right policy responses. A key learning outcome of the project was that a consistent methodological approach can greatly assist in creating awareness amongst spatial policy-makers of the overarching supra-national monitoring context and, in this way, help avoid unintended sub-national adverse territorial impacts as national governments strive to achieve Europe 2020 targets. 
And finally, while a consensus was reached between the KITCASP project team and the case study stakeholders on a common and coherent final set of indicators, it is recognised that there is no 'one-set-fits-all' solution. Data-availability, and mismatches between the data collected at different geographical scales and over time, remain a significant obstacle. At the sub-national scale, many Member States have developed powerful spatial monitoring tools with web-based interfaces on a wide range of issues including poverty, well-being, health, air quality, innovation, accessibility and the structure of settlements, but more remains to be done to complete the picture, harmonise the data and crucially connect these spatial data to national and supra-national monitoring. This chimes with the current renewed emphasis on reformed regional governance to ensure the impact of Cohesion Policy is maximised as an effective investment tool (CEC, 2014). The regional dimension of governance is of increasing importance in many parts of the EU as the authorities concerned acquire more autonomy and more responsibility for public policy and expenditure. This implies the need for better mechanisms for improving policy and programme design, monitoring and evaluation at national and sub-national level. While further studies are required, perhaps the real-added value of the KITCASP project, particularly its iterative dialogical method, was to provide a critical first-step empirical study in fulfilling a key objective of TA2020 of cross-fertilising Europe 2020, wider Cohesion Policy and strategic spatial planning policies. 


\section{References}

Al (2003) European common indicators: Towards a local sustainability profile. Ambiente Italia.

ALBRECHTS, L. (2013) Trends and policies in strategic spatial planning and regional governance in Europe. In: Pálné, I.K., Scott, J and Zoltán, G (eds) Territorial cohesion in Europe: For the 70th anniversary of the Transdanubian Research Institute. Institute for Regional Studies, Centre for Economic and Regional Studies and Hungarian Academy of Sciences, Pécs.

AMBROZIAK, A.A. (ed.) (2014) New cohesion policy of the European Union in Poland: How it will influence the investment attractiveness of regions in 2014-2020. Springer.

BARCA, F. (2009) An agenda for a reformed cohesion policy: A place-based approach to meeting European Union challenges and expectations. Brussels: European Commission. http://ec.europa.eu/regional_policy/archive/policy/future/barca_en.htm.

BASQUE GOVERNMENT (2012) Modificación de las DOT como consecuencia de su Reestudio, Department of the Environment, Spatial Planning, Agriculture and Fisheries, Basque Government, Vitoria, http://www.ingurumena.ejgv.euskadi.net/r49565/es/contenidos/informacion/dots_reestudio/es_1165/reestudioc.html

BRISTOW, G. and HEALY, A. (2014) Regional resilience: An agency perspective. Regional Studies 48, 5, 923-935.

BURLS A. (2007) People and green spaces: Promoting public health and mental well-being through ecotherapy, Journal of Public Mental Health 6,24-39.

CEC (1999) European spatial development perspective - Towards balanced and sustainable development of the territory of the European Union, Committee on Spatial Development, Commission of the European Communities, Brussels.

CEC (2000) Directive 2000/60/EC, of 23rd October, establishing a framework for community action in the field of water policy, Official Journal of the European Union L327,1-73, 22 December, Commission of the European Communities, Brussels.

CEC (2001) Directive 2001/42/EC, of 27th June, on the assessment of the effects of certain plans and programmes on the environment, Official Journal of the European Union, L197/30, 21.7.2001, Commission of the European Communities, Luxemburg.

CEC (2007) Directive 2007/60/EC, of 23rd October, on the assessment and management of flood risks, Official Journal of the European Union L288,27-34, 6 November, Commission of the European Communities, Brussels.

CEC (2010) Europe 2020: A strategy for smart, sustainable and inclusive growth, Commission of the European Communities, Brussels.

CEC (2011a) Territorial agenda of the European Union 2020: Towards an inclusive, smart and sustainable Europe of diverse regions, Commission of the European Communities, Hungary

CEC (2011b) The territorial state and perspectives of the European Union: 2011 update Background document for the territorial agenda of the European Union. Presented at the Informal Meeting of the Ministers responsible for Spatial Planning and Territorial 
Development on 19th May 2011, Godollo, Commission of the European Communities, Hungary.

CEC (2014) Investment for jobs and growth: Promoting development and good governance in EU regions and cities - Sixth report on economic, social and territorial cohesion, Commission of the European Communities, Brussels. URL: http://ec.europa.eu/regional_policy/sources/docoffic/official/reports/cohesion6/index_e n.cfm.

CHRISTOPHERSON S., MICHIE J. and TYLER P. (2010) Regional resilience: Theoretical and empirical perspectives, Cambridge Journal of Regions, Economy and Society 3, 3-10.

CLIFFORD C.W. and COBB J.B. (1994) The green national product: A proposed Index of Sustainable Economic Welfare, Lanham MD, University Press of America, New York.

COAFFEE J. (2013) Towards next-generation urban resilience in planning practice: From securitization to integrated place making, Planning Practice and Research 28, 3, 323-339.

COPUS, A.K. (2010) Assessing the impact of rural development policies. Deliverables 4.1, 4.2, 5.1 and 5.2: A review of planned and actual rural development expenditure in the EU 2007-2013. Framework Programme $7 . \quad$ http://www.rudieurope.net/uploads/media/Deliverables_WP4-5_Update_May_2010.pdf

DALY G. and GONZÁLEZ A. (2013) Key indicators for territorial cohesion and spatial planning: The reform of the EU Cohesion Policy and the new role of spatial indicators, Borderlands: The Journal of Spatial Planning in Ireland 3,77-89.

DAVOUDI S. (2006) Evidence-based planning: Rhetoric and reality, disP- The Planning Review $42,165,14-24$.

DONNELLY A., JENNINGS E., MOONEY P., FINNAN F., LYNN D., JONES M., O'MAHONY T., THERIVÉL R. and BYRNE G. (2006) Workshop approach to developing objectives, targets and indicators for use in SEA, Journal of Environmental Assessment Policy and Management 8, 2, 135-155.

DUHR, S., COLOMB, C., and NADIN, V. (2010) European spatial planning and territorial cooperation. London and New York: Routledge, Taylor \& Francis Group.

EC (1992) Directive 92/43/EEC, of 21st May, on the conservation of natural habitats and of wild fauna and flora, Official Journal of the European Union L206,7-50, 22 July, European Commission, Brussels.

EC (2003) Directive 2003/87/EC of the European Parliament and of the Council, of 13 October, establishing a scheme for greenhouse gas emission allowance trading within the Community and amending Council Directive 96/61/EC, Official Journal of the European Union L275,32-46, 25 October, European Commission, Brussels.

EC (2007) Directive 2007/2/EC of the European Parliament and of the Council, of 14 March, establishing an infrastructure for spatial information in the European Community (INSPIRE), Official Journal of the European Union L108,1, 25 April, European Commission, Brussels.

EC (2010) Analysis of options to move beyond $20 \%$ greenhouse gas emission reductions and assessing the risk of carbon leakage, Communication from the Commission to the European Parliament, the Council, the European Economic and Social Committee and the Committee of the Regions, 265 final, 26 May, European Commission, Brussels. 
EC (2012) Elements for a Common Strategic Framework 2014 to 2020, The European Regional Development Fund, the European Social Fund, the Cohesion Fund, the European Agricultural Fund for Rural Development and the European Maritime and Fisheries Fund, 61 final, 14 March, European Commission, Brussels.

EEA (2012) Environmental Indicators Report, European Environment Agency, Copenhagen.

EEC (1985) Council decision 85/338/EEC, of 27th June, on the adoption of the Commission work programme concerning an experimental project for gathering, coordinating and ensuring the consistency of information on the state of the environment and natural resources in the Community, Official Journal of the European Communities L176,14-17, 6 July, European Economic Community, Brussels.

ERIKSSON R.H. and HANSEN H.K. (2013) Industries, skills, and human capital: How does regional size affect uneven development? Environment and Planning A 45, 3, 593-613.

ESPON (2007) Monitoring territorial development, European Observation Network for Territorial Development

and

Cohesion,http://www.espon.eu/main/Menu_Projects/Menu_ESPON2006Projects/Menu_ ScientificBriefingNetworking/

ESPON (2012a) Indicators of territorial cohesion, European Observation Network for Territorial Development and Cohesion, http://www.espon.eu/main/Menu_Projects/Menu_ScientificPlatform/interco.html

ESPON (2012b) Territorial performance monitoring, European Observation Network for Territorial Development and Cohesion, http://www.espon.eu/main/Menu_Projects/Menu_TargetedAnalyses/TPM.html

ESPON (2013) Indicators and perspectives for services of general interest in territorial cohesion and development, SeGI - Applied research 2013/1/16, draft final report, http://www.espon.eu/main/Menu_Projects/Menu_AppliedResearch/SeGI.html

EU (2011) Territorial Agenda 2020 - Towards an inclusive, smart and sustainable Europe of diverse regions. European Union, Agreed at the Informal Ministerial Meeting of Ministers responsible for Spatial Planning and Territorial Development on 19 May, Gödöllö, Hungary, http://www.eu2011.hu/files/bveu/documents/TA2020.pdf

EUROSTAT (2013) Eurostat regional yearbook 2013, Publications Office of the European Union, Luxembourg, http://epp.eurostat.ec.europa.eu/cache/ITY_OFFPUB/KS-HA-13001/EN/KS-HA-13-001-EN.PDF

FALUDI, A. and WATERHOUT, B. (2006) Introducing evidence-based planning, disP - The Planning Review 165, 2, 4-13.

GONZÁLEZ A. (2012) GIS in environmental assessment: A review of current issues and future needs, Journal of Environmental Assessment Policy and Management, 14, 1-23.

GONZÁLEZ A., DONNELLY A., JONES M., KLOSTERMANN J., GROOT A. and BREIL M. (2011) Community of practice approach to developing urban sustainability indicators, Journal of Environmental Assessment Policy and Management 13, 4, 591-617.

GOVERNMENT OF IRELAND (2002) National spatial strategy 2002-2020, Government Publications, Dublin, http://nss.ie/pdfs/Completea.pdf

GOVERNMENT OF LATVIA (2007) National development plan 2007-2013, http://www.latvija2030.Iv 
HUDSON R. (2010) Resilient regions in an uncertain world: Wishful thinking or a practical reality? Cambridge Journal of Regions, Economy and Society 3, 11-25.

HUDSON R. (2011) From knowledge-based economy to...Knowledge-based economy? Reflections on changes in the economy and development policies in the North East of England, Regional Studies, 45, 7, 997-1012.

ICELANDIC PLANNING AGENCY (2012) Icelandic national planning strategy, http://www.landsskipulag.is/

LEGACY C. (2010) Investigating the knowledge interface between stakeholder engagement and plan-making, Environment and Planning A 42, 11, 2705-2720.

MARTIN R.L. (2012) Regional economic resilience, hysteresis and recessionary shocks, Journal of Economic Geography 12, 10-32.

MEDEIROS E. (2010) Territorial cohesion trends in inner Scandinavia: The role of crossborder cooperation, INTERREG-A 1995-2010, http://ww3.fl.ul.pt/pessoais/Eduardo_Medeiros/docs/PUB_PAP_EM_Territorial_Cohesio n_trends_in_IS.pdf

MENDEZ, C. (2012) The post-2013 reform of EU cohesion policy and the place-based narrative. Journal of European Public Policy, 20 (5): 639-659.

MORRIS M.D. (1980) The Physical Quality of Life Index (PQLI), Development Digest 18, 1,95109.

NAGY, S.G. and LÓRÁND, B. (2013) Evaluation of EU fund dependency - Dead weight loss and substitution effect. In: Pálné, I.K., Scott, J and Zoltán, G (eds) Territorial cohesion in Europe: For the 70th anniversary of the Transdanubian Research Institute. Institute for Regional Studies, Centre for Economic and Regional Studies and Hungarian Academy of Sciences, Pécs.

NEF (2005) Well-being and the environment - Achieving 'One Planet Living' and maintaining quality of life, New Economics Foundation, London, http://www.neweconomics.org/

NEF (2012) Happy Planet Index: A global index of sustainable well-being, New Economics Foundation, London.

NICHOLSON M. and FRYER R. (2002) Developing effective environmental indicators - does a new dog need old tricks? Marine Pollution Bulletin 45, 1-12, 53-61.

OECD (2013) Better Life Index, Organisation for Economic Cooperation and Development, http://www.oecdbetterlifeindex.org/

OOSTINDIE, H. and VAN BROEKHUIZEN, R. (2010) Assessing the impact of rural development policies. Deliverable 8.2: Case-study synthesis report. Framework Programme 7. http://www.rudi-europe.net/uploads/media/WP_8_Synthesis_Report.pdf

POTLUKA, O. (2010) Impact of EU cohesion policy in central Europe, Leipziger Universitätsverlag.

SCHOMAKER M. (1997) Development of environmental indicators in UNEP, paper presented at the Land Quality Indicators and their Use in Sustainable Agriculture and Rural Development, 25-26 January 1996, Rome, FAO, pp. 35-36, http://www.fao.org/docrep/W4745E/w4745e07.htm

SIEDENTOP S. and FINA S. (2012) Who sprawls most? Exploring the patterns of urban growth across 26 European countries, Environment and Planning A 44, 11, 2765-2784 . 
SMEETS E. and WETERINGS R. (1999) Environmental indicators: Typology and overview, Report no. 25, European Environmental Agency, Copenhagen.

THE SCOTTISH GOVNERMENT (2009) National planning framework for Scotland 2, http://www.scotland.gov.uk/Publications/2009/07/02105627/0

UNDESA (2007) Indicators of sustainable development: Guidelines and methodologies, 3rd Edition, United Nations Department of Economic and Social Affairs, http://sustainabledevelopment.un.org/content/documents/guidelines.pdf

UNDP (2013) Human development report - The rise of the south, human progress in a diverse world, United Nations Development Programme, Oxford University Press, New York.

UNECE (2012) Draft report of the joint UNECE/Eurostat/OECD task force on measuring sustainable development, United Nations Economic Commission for Europe, http://www.unece.org/index.php?id=32146

UNEP (2012) Key environmental indicators - Tracking progress towards environmental sustainability, United Nations Environment Programme, http://www.unep.org/yearbook/2012/pdfs/UYB_2012_CH_4.pdf

WHO (1998) Use of well-being measures in primary health care - The DepCare Project, Health for All, Target 12, World Health Organisation, Regional office for Europe.

WWF (2008) Living planet report, World Wildlife Foundation, http://assets.panda.org/downloads/living_planet_report_2008.pdf 